\title{
REVIEW
}

\section{Episodes of falling among elderly people: a systematic review and meta-analysis of social and demographic pre-disposing characteristics}

\author{
F. Bloch, ",II M. Thibaud, "I,III B. Dugué," C. Brèque,"II AS. Rigaud,' G. Kemoun",IV \\ 'Department of Gerontology, Assistance Publique-Hôpitaux de Paris (Hôpital Broca), Paris, France. "University of Poitiers, Laboratory of Exercise-Induced \\ Physiological Adaptations, Poitiers, France. "'P 'UPR Institute 3346, University of Poitiers, Poitiers, France. ' ${ }^{\text {IV }}$ Fondation Hospitalière Sainte Marie, Paris, France.
}

CONTEXT: The multifactorial nature of falls among elderly people is well-known. Identifying the socialdemographic characteristics of elderly people who fall would enable us to define the typical profile of the elderly who are at risk of falling.

OBJECTIVE: We aimed to isolate studies in which the social-demographic risk factors for falls among the elderly have been evaluated and to carry out a meta-analysis by combining the results of all of these selected studies.

METHOD: We did a systematic literature review using the key words "accidental fall / numerical data" and "risk factors." Inclusion criteria entailed the selection of articles with the following characteristics: population of subjects aged 60 years or over, falls that took place in everyday life, and social-demographic risk factors for falls.

RESULTS: 3,747 indexed articles published between 1981 and 2007 were identified, and 177 studies with available data were included, of which 129 had data on social-demographic risk factors for falls. Difficulties in activities of daily living $(A D L)$ or in instrumental activities of daily living (IADL) double the risk of falling: The OR and $95 \% \mathrm{Cl}$ were $2.26(2.09,2.45)$ for disturbance $A D L$ and $2.10(1.68,2.64)$ for IADL. The OR and $95 \%$ Cl for Caucasians were $1.68(0.98-2.88)$ and $0.64(0.51-0.80)$ for Hispanics. In the subgroup of patients older than eighty, being married protected people from falling with an OR and $95 \% \mathrm{Cl}=0.68(0.53-0.87)$.

CONCLUSION: Defining factors that create a risk of falling and protect elderly people from falls using socialdemographic characteristics lets us focus on an "at risk" population for which a specific program could be developed.

KEYWORDS: Social-demographic characteristics; Risk factors; Falls; Elderly; Meta-analysis.

Bloch F, Thibaud M, Dugué B, Brèque C, Rigaud, AS. Episodes of falling among elderly people: a systematic review and meta-analysis of social and demographic pre-disposing characteristics. Clinics. 2010;65(9):895-903.

Received for publication on May 17, 2010; First review completed on May 21, 2010; Accepted for publication on May 31 , 2010

E-mail: frederic.bloch@brc.aphp.fr

Tel.: 33144083521

\section{INTRODUCTION}

Several studies have demonstrated the multifactorial nature of falls among the elderly. ${ }^{1,2}$ The consequences of such an event, beyond the dangers of morbidity and mortality, are a loss of autonomy and a significant risk of institutionalization. ${ }^{3-5}$ This loss of autonomy and institutionalization, which were already identified in reviews on this topic, highlight the spiral into which the elderly person who experiences a fall descends, and then there are further factors that increase the risk of more falls. ${ }^{6}$ During a visit to the emergency department (ED) after a fall, at-risk populations could be identified. However, the medical staff is

Copyright (c) 2010 CLINICS - This is an Open Access article distributed under the terms of the Creative Commons Attribution Non-Commercial License (http:// creativecommons.org/licenses/by-nc/3.0/) which permits unrestricted noncommercial use, distribution, and reproduction in any medium, provided the original work is properly cited. nearly always reassured by the absence of traumatic consequences, and they propose no medical or environmental changes for those discharged after their ED visit. ${ }^{7}$

Identifying the social-demographic characteristics of this population would enable us to define the typical profile of the elderly people at risk of falling. These data could be extremely useful to guide at-risk subjects and to develop preventative programs.

The purpose of this study, therefore, was to identify studies where social-demographic risk factors for falls among elderly subjects were evaluated and then to conduct a meta-analysis for each of the identified risk factors to determine the adjusted odds ratios.

\section{MATERIAL AND METHODS}

Search strategy and selection of articles

Original articles published in English or French between 1996 and 2007 were collected using a computerized search 
on the MEDLINE and the Cochrane Collaboration databases. A manual search for the articles cited within the previously identified publications completed the compilation. The keywords used were the MeSH terms "accidental fall / numerical data" and "risk factors." "Numerical data" was used to capture articles focusing on quantitative data.

Articles were selected if they were (i) studies involving a population aged over 60 , (ii) pertaining to falls in daily life (excluding falls from ladders, scaffolding, and cliffs and/or those involving a cohort suffering from serious neuromuscular disease), and (iii) targeting one or more risk factors for falls. Letters to the editor, commentaries, editorials, and meta-analyses were not selected.

Evaluation of articles allowed us to exclude some of them, mainly for technical reasons. Those not selected lacked data on the main evaluation criteria. We also discarded articles about the same study published in different journals.

This article focuses on a systematic research of all articles that include information about social-demographic characteristics in the elderly that are risk factors for falls, namely the age, gender, ethnicity, marital status, place of residency, autonomy, level of education, and income.

\section{Data Extraction and quality assessment}

Two readers (MT \& FB) independently selected all the abstracts of articles derived from the search. Each reader gathered information on half of the studies. To detect potential bias in the data abstraction process, data from a randomly selected $25 \%$ of articles were independently extracted by each of the two readers in order to evaluate the degree of inter-reader concordance. Discrepancies were resolved by consensus with a third party if necessary (GK). Few discrepancies were observed (6.4\% error), and a double extraction on all items was not performed.

The quality of each study chosen was assessed by two readers using a validated scale proposed by the ANAES ${ }^{8}$ and derived from the recommendations of Cook et al. ${ }^{9}$ This scale gave a level of proof for function of methodology, study power, randomization, population, data collection, and biases. Level 1 proof is synonymous with established scientific proof, level 2 denotes scientific assumption, and levels 3 and 4 refer to a low degree of scientific proof.

The abstracted data included the study characteristics (including quality criteria), the patient characteristics, and fall definitions (one or more falls, more than one fall, and traumatic falls). For qualitative variables, the following frequencies were collected: number of fallers with a risk factor for falls, number of fallers without a risk factor for falls, number of non-fallers with a risk factor for falls, number of non-fallers without a risk factor for falls. For quantitative variables, the mean and standard deviation for the groups of fallers and non-fallers were collected.

\section{Statistical analysis}

A meta-analysis was performed for each social-demographic characteristic. The odds ratio (OR) and confidence interval of $95 \%$ were estimated for each study and overall to assess the risk of falls associated with these characteristics. The fixed-effects method proposed by MantelHaenszel $^{10}$ was used. Heterogeneity between studies was assessed using standard methods, in particular the Chisquare test ${ }^{11}$ and the $\mathrm{I}^{2}$ statistic. ${ }^{12} \mathrm{~A}$ value of $\mathrm{I}^{2}$ less than $25 \%$ indicates low heterogeneity, and a value between 25 to $50 \%$ indicates moderate heterogeneity. Regardless of the statistical significance of the $\mathrm{Q}$ test, ${ }^{13}$ we applied a random effects model that allows meta-analysis to consider between-study variations. In cases of significant heterogeneity, some features that might be potential sources of heterogeneity received special attention (population, intervention endpoint). We conducted stratified analysis of these characteristics or analyses of sensitivity based on the methodological quality of the studies. We also used Begg's funnel plots ${ }^{14}$ and Egger's test ${ }^{15}$ to detect possible publication bias. All statistical tests were conducted with the Review Manager software suite RevMan Version 5.0 (Copenhagen: The Nordic Cochrane Centre, The Cochrane Collaboration, 2008). We defined a statistical test with a $p$ value of less than 0.05 as significant.

\section{RESULTS}

\section{Trial Flow}

The flow chart of our study is shown in Figure 1. The computerized search strategy identified 3,747 articles published from 1981 to 2007. We excluded 3,219 articles, retaining only 326 articles, then added 36 references from the manual search to obtain 362 studies. After verifying the data and removing duplicates, we included 177 studies, 129 of which specifically presented data on social-demographic characteristics as risk factors for a fall. ${ }^{16-141}$ The "funnel plots" of each meta-analysis, representing the estimated values of the OR according to the size of the population, were distributed symmetrically.

\section{Study Characteristics}

Twenty-four social-demographic conditions were identified as a risk factor for falls: age, gender, ethnicity (5 conditions), marital status (3 conditions), lifestyle (6 conditions), autonomy (5 conditions), level of education, and income (2 conditions). The 129 articles were published between 1981 and 2007. Eighty-two studies had as a main outcome the occurrence of one or more falls, 9 studies included the occurrence of more than one fall, and 5 studies included the occurrence of traumatic falls. The number of elderly subjects participating in these studies was between 33 and 1,1390 reporting between 13 and 2,278 falls; this represents a prevalence ranging from less than $5 \%$ falls to more than $65 \%$ (i.e., an average prevalence of $35.5 \%$ in these studies). The mean age was 78.6 years (68.1 to 88.5$)$. Sixty percent of studies $(n=57)$ included follow-up periods of 7 to 12 months, $19 \%$ were under or equal to 6 months, $11 \%$ from 13 to 24 months, and $2 \%$ over 24 months.

\section{Study quality}

Based on the methodological characteristics selected, only $2 \%$ of the studies selected were ranked as containing level 1 evidence (i.e., randomized controlled trials of high power). All except one were observational studies, 37 studies were cohort studies (39\%) with level 2 evidence, and 16 studies were case-control studies with level 3 evidence (17\%). Fortyone were cross-sectional (44\%) and were considered to have a low level of scientific evidence (level 4).

\section{Results of meta-analysis}

An OR with $95 \%$ CI could be calculated for the female subjects in 88 studies. Its value was $1.52(1.45$ - 1.59) but with a high heterogeneity. Stratified analyses (Table 1) were used to calculate the OR depending on the type of fall and age or 


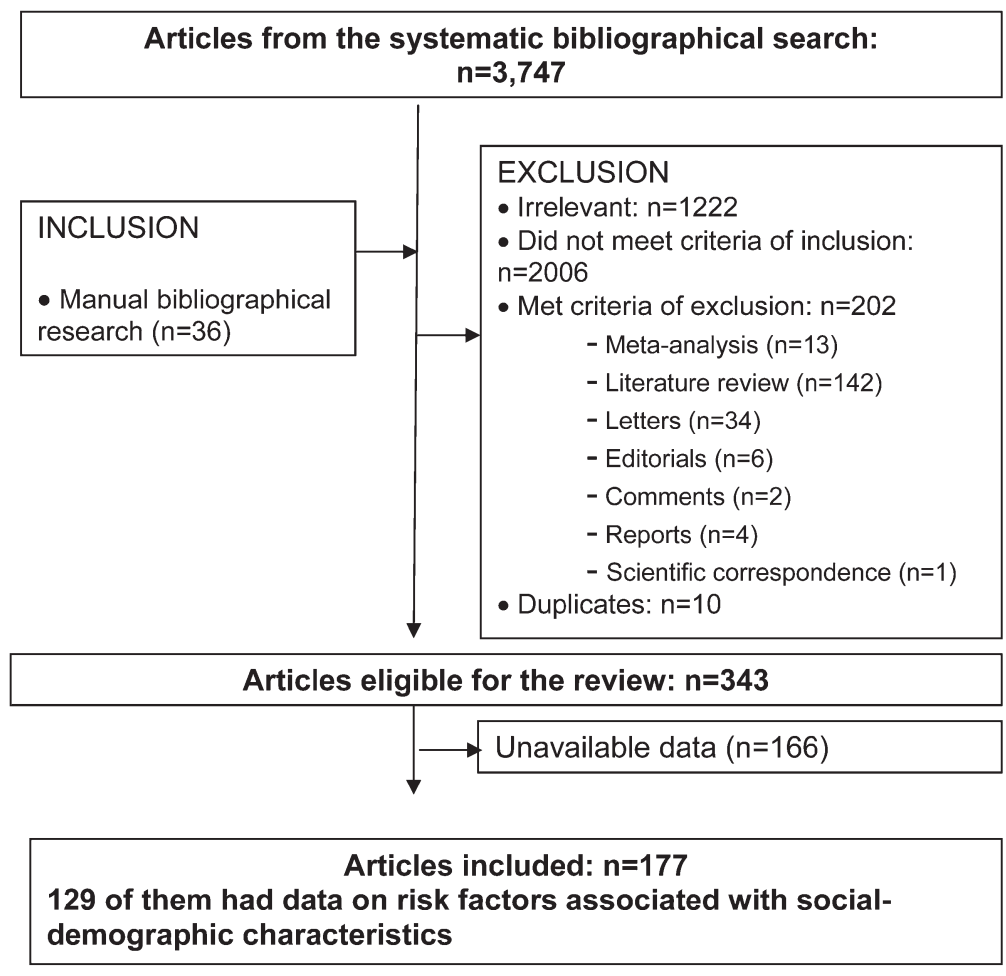

Figure 1 - Flowchart of the studies involved in systematic review.

living environment. Only the institutionalized group of patients gave homogeneous results for an OR of 1.15 (95\% CI 1.02 - 1.29). Data on age were present in 57 articles, allowing us to calculate an average age difference for the fall. The results are presented in Table 1 . Two metaanalyses were carried out for ethnicity. The OR and 95\% Cl for Caucasians were 1.68 (0.98 - 2.88); the corresponding value for Hispanics was 0.64 (0.51 - 0.80). These two results were homogenous. It was not possible to perform a metaanalysis for Australians, Asians, and African-Americans because there was an insufficient number of good-quality studies.
The OR and 95\% Cl were $2.26(2.09,2.45)$ (Figure 2a) for disturbance of one or more activities of daily living (ADL), $2.10(1.68,2.64)$ for disturbance of one or more instrumental activities of daily living (IADL), $2.18(1.74,2.73)$ for motor autonomy limited to the neighbourhood, and 1.73 (1.44, 2.08) for institutionalized patients. These results were homogenous except for those on ADL (Table 2), but for this group, data became homogenous in the subgroup of ambulatory patients.

The OR and $95 \% \mathrm{Cl}$ were not significant for the condition of low education level $(0.97(0.83-1.13))$, married status (1.04 (0.94 - 1.15)); Fig. 2b), confined to bed (0.92 (0.70 -

Table 1 - Pooled Odds Ratios (OR) and subgroup sensitivity analysis for gender and age.

\begin{tabular}{|c|c|c|c|c|}
\hline Study Characteristic & $\mathbf{n}$ & Gender OR (95\% Cl) & $\mathbf{n}$ & Age Mean Difference (Fixed, $95 \% \mathrm{Cl}$ ) \\
\hline No. of studies & & 88 & & 57 \\
\hline No. of subjets & & 92025 & & 50431 \\
\hline Population & 49 & $1.52[1.45,1.59]$ & 30 & $2.65[2.69,2.60]$ \\
\hline \multicolumn{5}{|l|}{ Living } \\
\hline Institution & 17 & $1.15[1.02,1.29]^{*}$ & 10 & $1.12[1.57,0.67]$ \\
\hline Ambulatory & 28 & $1.69[1.61,1.79]$ & 20 & $2.66[2.71,2.62]$ \\
\hline Both & 4 & $0.76[0.63,0.92]$ & 0 & na \\
\hline \multicolumn{5}{|l|}{ Evaluation criteria } \\
\hline One or more falls & 37 & $1.53[1.44,1.62]$ & 25 & $2.65[2.70,2.61]$ \\
\hline More than one fall & 8 & $1.35[1.14,1.60]$ & 5 & $1.69[2.35,1.03]^{*}$ \\
\hline Traumatic falls & 4 & $1.53[1.41,1.67]$ & 0 & na \\
\hline \multicolumn{5}{|c|}{ Mean age of study subjects } \\
\hline$>80$ years & 21 & $1.02[0.92,1.14]$ & 12 & $1.19[1.62,0.76]^{* *}$ \\
\hline$\leq 80$ years & 19 & $1.75[1.65,1.85]$ & 18 & $2.66[2.71,2.62]$ \\
\hline Unknown & 9 & $1.25[1.10,1.42]$ & 0 & na \\
\hline
\end{tabular}

$\mathrm{Cl}=$ confidence interval;

* good homogeneity with $\mathrm{I}^{2}<25 \%$

${ }^{* \star}$ Moderate homogeneity with $25 \leq 1^{2}<50 \%$. 


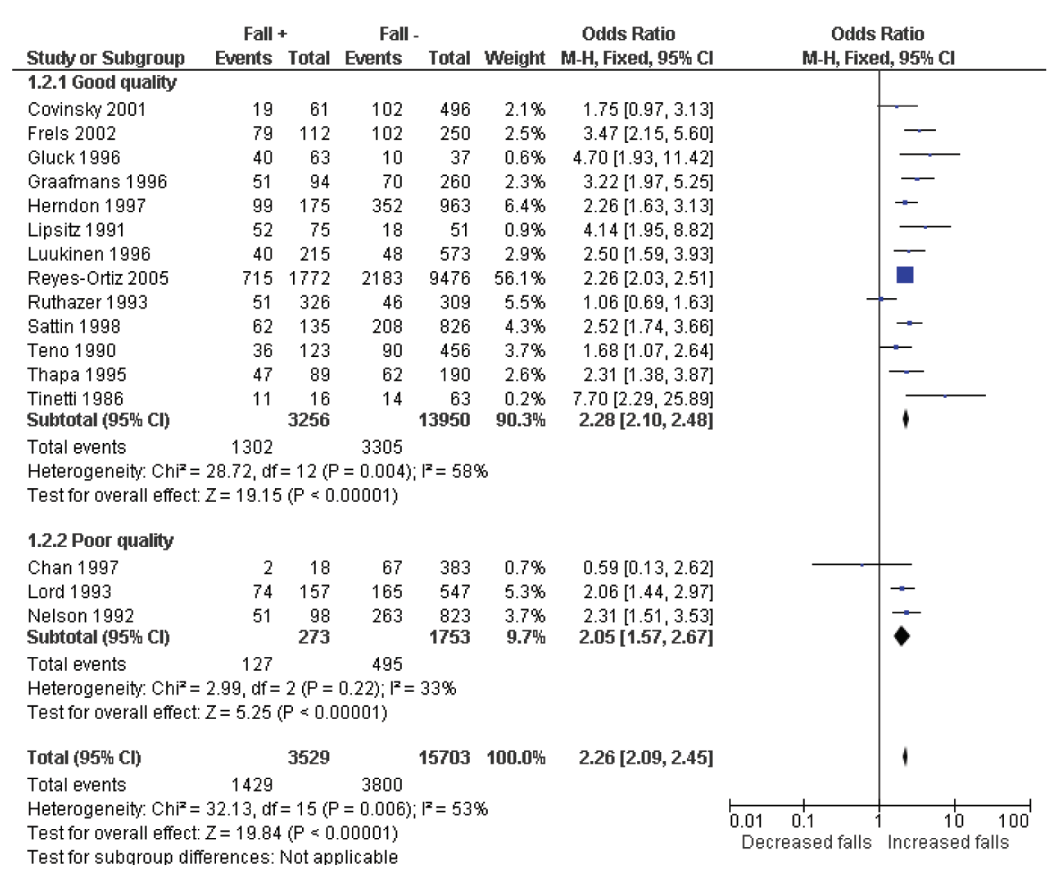

a) disturbance of one or more $A D L$

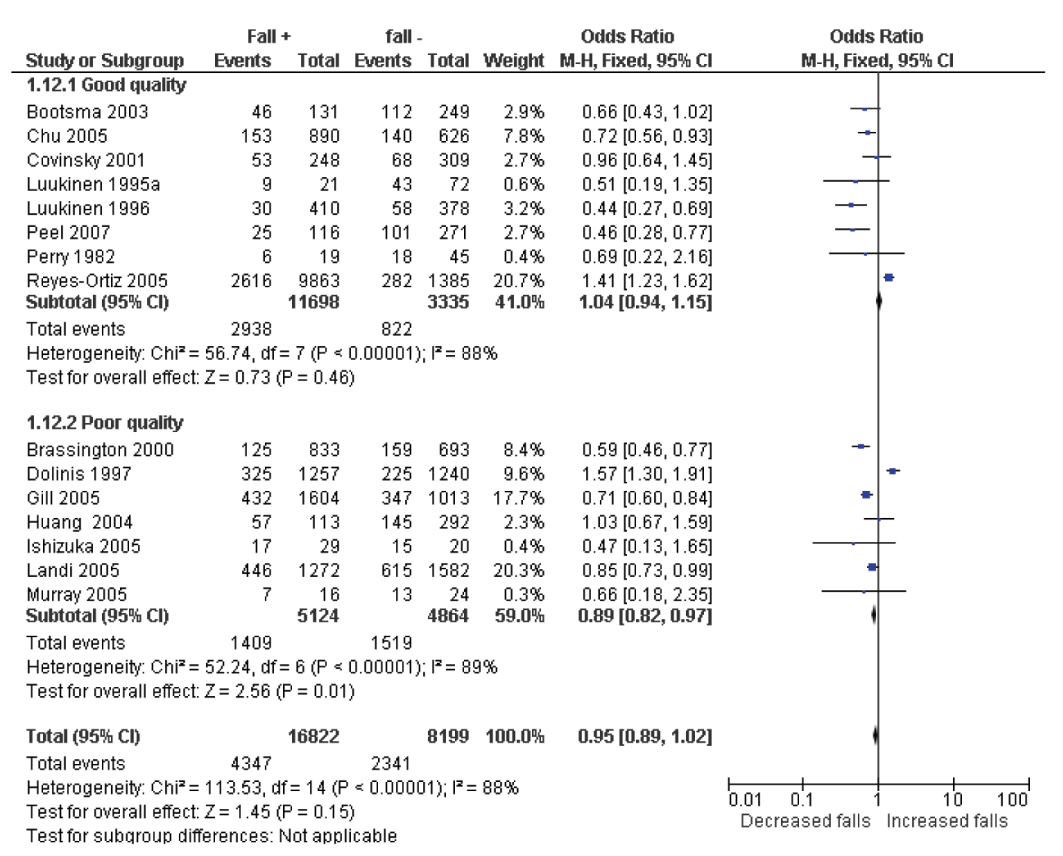

\section{b) married}

Figure 2 - Examples of forest plots for 3 characteristics.

$1.20))$, presence of a caregiver $(1.26(0.99-1.60))$, and in the limit of significance for "living alone" (1.16 (1.02 - 1.32); Fig. 2c (Table 3)). However, in the subgroup of patients older than eighty, being married was protective against falling with an OR and $95 \% \mathrm{Cl}=0.68(0.53-0.87)$ with a moderate homogeneity.

Because there were an insufficient number of studies of good quality, we were not able to perform a meta-analysis on conditions such as widowed or divorced, help for transfers, income less than $\$ 25,000$, non driving, and mean Barthel index.

\section{DISCUSSION}

Our results confirm that loss of autonomy is a major risk factor for falls: difficulties in at least one activity of daily living or instrumental activities of daily living double the risk of falling. Similarly, a decrease of motor autonomy limited to the neighborhood and an institutionalization, where subjects witnessed the loss of functional or motor autonomy, increases the risk of falling in similar ratios.

These results are coherent with other studies showing that fall risk is closely related to ADL capability and that the 


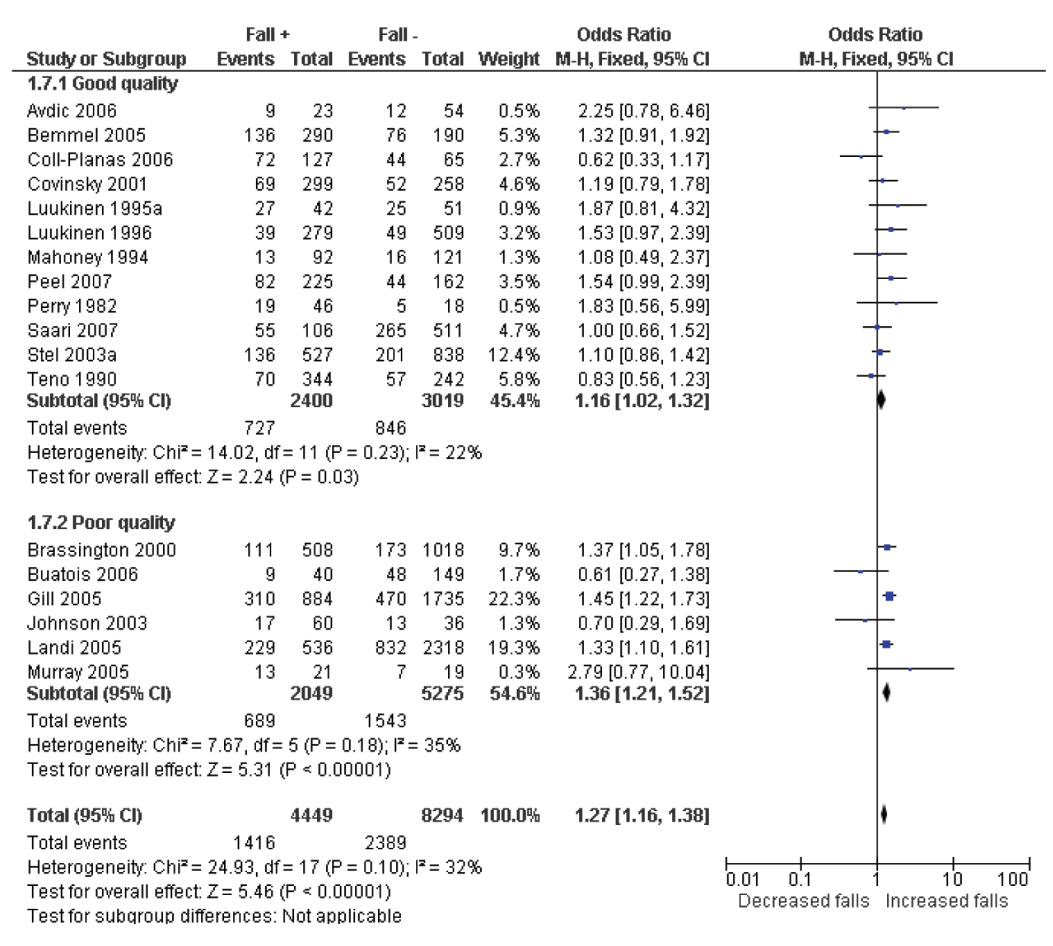

\section{c) living alone}

Figure 2 - Continued.

maintenance of a high frequency of activity external to the house is very important for reducing fall risk. ${ }^{142}$ One explanation given was that there is a possible link between bone loss in elderly subjects and reduction of ADL. Oka et al. analysed the association between decreased ADL and annual bone changes after adjustment for age and concomitant disease and showed that annual rates of change in bone mineral density were significantly correlated with decreased ability to bend down from a seated position and to pick up small objects by the side of the chair for men and in reaching objects on a high shelf or cupboard and lifting heavy objects for women. ${ }^{143}$
The interaction of loss of autonomy, fear of falling, and risk of falls could be another explanation. Compared with those with a high score on the falls efficacy scale (FES), a 10-item rating scale to assess confidence in performing daily activities without falling, ${ }^{144}$ those with a low fall-related self-efficacy score had an increased risk of falling and had a greater decline in their ability to perform ADLS ( $p<.001)$ : the total ADL score decreased by 0.69 activities among persons with low FES scores $(\leq 75)$ but decreased by only 0.04 activities among persons with FES scores of 100. Furthermore, nonfallers who said they were afraid of falling had an increased risk of admission to an institution. ${ }^{145}$

Table 2 - Pooled Odds Ratios (OR) and subgroup sensitivity analysis for elements of autonomy.

\begin{tabular}{|c|c|c|c|c|c|c|c|c|}
\hline Study Characteristic & $\mathbf{n}$ & $\begin{array}{l}\text { disturbance of one or } \\
\text { more ADL OR }(95 \% \mathrm{CI})\end{array}$ & $\mathbf{n}$ & $\begin{array}{l}\text { disturbance of one or } \\
\text { more IADL OR }(95 \% \mathrm{CI})\end{array}$ & $\mathbf{n}$ & $\begin{array}{c}\text { Autonomy limited to the } \\
\text { neighbourhood OR }(95 \% \mathrm{Cl})\end{array}$ & $\mathbf{n}$ & $\begin{array}{l}\text { In stitution alised } \\
\text { OR }(95 \% \mathrm{Cl})\end{array}$ \\
\hline No. of studies & & 16 & & 5 & & 8 & & 10 \\
\hline No. of subjets & & 19232 & & 2957 & & 2316 & & 5925 \\
\hline Population & 13 & $2.26[2.09,2.45]$ & 4 & $2.10[1.68,2.64]^{*}$ & 7 & $2.18[1.74,2.73]^{*}$ & 7 & $1.73[1.44,2.08]^{*}$ \\
\hline \multicolumn{9}{|l|}{ Living } \\
\hline Institution & 5 & $2.23[1.75,2.86]$ & 0 & na & 1 & $1.31[0.67,2.55]$ & na & - \\
\hline Ambulatory & 8 & $2.29[2.09,2.51]^{*}$ & 4 & $2.10[1.68,2.64]^{*}$ & 6 & $2.34[1.83,2.98]^{*}$ & na & - \\
\hline Both & 0 & na & 0 & na & 0 & na & na & - \\
\hline \multicolumn{9}{|l|}{ Evaluation criteria } \\
\hline One or more falls & 7 & $2.25[2.05,2.48]$ & na & - & 6 & $2.14[1.68,2.73]^{*}$ & 5 & $1.65[1.35,2.02]$ ** \\
\hline More than one fall & 4 & $2.46[1.86,3.26]$ & na & - & 1 & $2.48[1.33,4.63]$ & 2 & $2.19[1.41,3.40]^{*}$ \\
\hline Traumatic falls & 2 & $2.37[1.85,3.03]^{*}$ & na & - & 0 & na & 0 & na \\
\hline \multicolumn{9}{|c|}{ Mean age of study subjects } \\
\hline$>80$ years & 6 & $2.11[1.69,2.65]$ & 2 & $2.27[1.69,3.06]^{*}$ & 3 & $3.29[1.68,6.43]^{*}$ & 4 & $1.59[1.28,1.98]^{* *}$ \\
\hline ? 80 years & 5 & $2.31[2.09,2.54]^{* *}$ & 2 & $1.89[1.33,2.70]$ & 3 & $1.72[1.24,2.39]^{*}$ & 3 & $2.17[1.54,3.04]^{*}$ \\
\hline Unknown & 2 & $2.37[1.85,3.03]$ & 0 & na & 1 & $2.48[1.33,4.63]$ & 0 & na \\
\hline
\end{tabular}

$\mathrm{Cl}=$ confidence interval;

*good homogeneity with $\mathrm{I}^{2}<25 \%$

${ }^{* *}$ Moderate homogeneity with $25 \leq \mathrm{I}^{2}<50 \%$. 
Table 3 - Pooled Odds Ratios (OR) and subgroup sensitivity analysis.

\begin{tabular}{|c|c|c|c|c|c|c|c|c|c|c|}
\hline Study Characteristic & $\mathbf{n}$ & $\begin{array}{c}\text { Low level of } \\
\text { education OR } \\
(95 \% \mathrm{Cl})\end{array}$ & $\mathbf{n}$ & $\begin{array}{c}\text { Married OR } \\
(95 \% \mathrm{Cl})\end{array}$ & $\mathbf{n}$ & $\begin{array}{l}\text { Living alone } \\
\text { OR (95\% Cl) }\end{array}$ & $\mathbf{n}$ & $\begin{array}{l}\text { Presence of a } \\
\text { caregiver OR } \\
(95 \% \mathrm{Cl})\end{array}$ & $\mathbf{n}$ & $\begin{array}{l}\text { Confined to bed } \\
\text { OR }(95 \% \mathrm{Cl})\end{array}$ \\
\hline No. of studies & & 8 & & 15 & & 18 & & 12 & & 5 \\
\hline No. of subjets & & 8557 & & 25021 & & 12743 & & 15557 & & 3627 \\
\hline \multicolumn{10}{|l|}{ Living } & $0.92[0.70,1.20]$ \\
\hline Institution & 0 & na & 1 & $0.51[0.19,1.35]$ & 1 & $1.87[0.81,4.32]$ & 3 & $1.15[0.85,1.57]$ & 2 & $0.81[0.60,1.07]$ \\
\hline Ambulatory & 4 & $0.97[0.83,1.13]^{*}$ & 7 & $1.05[0.94,1.16]$ & 8 & $1.12[0.97,1.31]^{*}$ & 2 & $1.44[0.99,2.09]^{*}$ & 1 & $3.89[1.58,9.56]$ \\
\hline Both & 0 & na & 0 & na & 3 & $1.22[0.93,1.60]^{*}$ & 0 & na & 0 & na \\
\hline \multicolumn{11}{|l|}{ Evaluation criteria } \\
\hline One or more falls & 1 & $1.14[0.89,1.48]$ & 5 & $1.15[1.03,1.28]$ & 5 & $1.14[0.91,1.44]^{*}$ & 5 & $1.26[0.99,1.60]$ & na & - \\
\hline More than one fall & 0 & na & 2 & $0.45[0.29,0.68]^{*}$ & 5 & $1.15[0.95,1.38]^{*}$ & 0 & na & na & - \\
\hline Traumatic falls & 3 & $0.88[0.73,1.07]^{*}$ & 1 & $0.46[0.28,0.77]$ & 2 & $1.07[0.72,1.59]^{*}$ & 0 & na & na & - \\
\hline \multicolumn{11}{|c|}{ Mean age of study subjects } \\
\hline$>80$ years & 1 & $1.06[0.69,1.62]$ & 4 & $0.68[0.53,0.87]^{* *}$ & 5 & $1.25[1.01,1.54]^{*}$ & 5 & $1.26[0.99,1.60]$ & na & - \\
\hline$\leq 80$ years & 1 & $1.14[0.89,1.48]$ & 3 & $1.14[1.02,1.28]$ & 5 & $1.12[0.93,1.34]^{*}$ & 0 & na & na & - \\
\hline Unknown & 2 & $0.84[0.68,1.04]$ & 1 & $0.69[0.22,2.16]$ & 2 & $1.22[0.93,1.60]^{*}$ & 0 & na & na & - \\
\hline
\end{tabular}

$\mathrm{Cl}=$ confidence interval;

*good homogeneity with $\mathrm{I}^{2}<25 \%$

${ }^{* *}$ Moderate homogeneity with $25 \leq 1^{2}<50 \%$.

Caucasian women seem also to be the ethnic group with the highest risk of falling. Moreover, having Hispanic origin and living in the United States seemed to protect against falls. This result is similar to findings made by Stevens et al. in 1998 showing that the fall-related death rate for nonHispanic women was 1.9 times the rate for Hispanic women. These results suggested that the subgroup analyses revealed what overall fall-related death rates for men and women did not reveal: the increasing death rates among whites and non-Hispanics. ${ }^{146}$ The longitudinal Study of Elderly Mexican American Health (H-EPESE) found a similar prevalence of falls among older Mexican Americans and non-Hispanic Caucasians, indicating that potential modifiable conditions, such as functional deficits, arthritis, diabetes, and depressive symptoms, were independent risk factors for falls in this population. Finally, these different medical conditions for Hispanics and non Hispanics representing the independent risk factors for falls can explain the possible ORs differences.

Our study also pointed out the protective effect of marriage against falling, even though it was only in the subgroup of patients over eighty, and we were not able to perform a meta-analysis on conditions such as widowed or divorced. Recent scientific work has already established a causal impact of social relationships on health, ${ }^{147}$ and researchers have recognized a relationship between marital status and mortality. This higher risk of death for both men and women has also been illustrated by a study showing that a spouse's admission to an institution was deleterious for the partner even when adjusted for underlying disorders. ${ }^{148}$ A meta-analysis of cohort studies was conducted by Manzoli et al. to produce an overall estimate of the excess mortality associated with being unmarried in elderly individuals and showed that marriage had a protective influence that remained significant, although the effect size was reduced $(R R=0.94 ; 0.92-0.95) .{ }^{149} \mathrm{~A}$ possible mechanism for this association was that illness or death of the spouse may impose stress on a partner that may deprive the partner of social, emotional, economic, or other practical support. ${ }^{150}$
To define protective factors and risk factors of falls from social-demographic characteristics lets us focus on the population at risk of falling for which a specific targeted program could be developed. Evidence for reducing the number of fallers or the number of falls with one of these programs, even under the very favorable conditions of randomized trials, has always been very modest. However, a recent study showed that a physical activity program can slow cognitive decline and improve quality of walking in elderly persons suffering from dementia. ${ }^{151}$ This is a good reason to specifically target those most at risk of falling for whom interventions will be most beneficial. ${ }^{152}$ The interventions proposed would thus be multifactorial and correspond to exercise programs, medication, and livingspace modifications, as appropriate. ${ }^{153}$

\section{REFERENCES}

1. Prudham D, Evans J. Factors associated with falls in the elderly: a community study. Age Ageing. 1981;10:141-146.

2. Perry BC. Falls among the elderly living in high-rise appartments. J Fam Pract. 1982;14:1069-1073.

3. Tinetti ME, Speechley M. Prevention of falls among the elderly. N Engl J Med. 1989;320:1055-1059, doi: 10.1056/NEJM198904203201606.

4. Oakley A, Dawson MF, Holland J, Arnold S, Cryer C, Doyle Y, et al. Preventing falls and subsequent injury in older people. Qual Health Care. 1996;5:243-249, doi: 10.1136/qshc.5.4.243.

5. Rivara FP, Grossman DC, Cummings P. Injury prevention. First of two parts. N Engl J Med. 1997;337:543-548.

6. Janken J, Reynolds B, Swiech K. Patient falls in the acute care setting: identifying risk factors. Nurs Res. 1986;35:215-219, doi: 10.1097/ 00006199-198607000-00007.

7. Bloch F, Jegou D, Dhainaut JF, Rigaud AS, Coste J, Lundy JE, Claessens YE. Do ED staffs have a role to play in the prevention of repeat falls in elderly patients? Am J Emerg Med. 2009;27(3):303-307, doi: 10.1016/j. ajem.2008.02.026.

8. Guide d'analyse de la litterature et gradation des recommandations. ANAES, Janvier 2000; 2000.

9. Cook D, Guyatt G, Laupacis A, Sackett D. Rules of evidence and clinical recommendations on the use of antithrombotic agents. Chest. 1992;102:305s-311S

10. Mantel N, Haenszel W. Statistical aspects of the analysis of data from retrospective studies of disease. J Natl Cancer Inst. 1959;22:719-748.

11. Egger M, Smith G, Altman D. Systematic reviews in health care. Metaanalysis in context.BMJ. 2001;

12. Higgins J, Thompson S, Deeks J, Altman D. Measuring inconsistency in meta-analysis. BMJ. 20023;327:557-560, doi: 10.1136/bmj.327.7414.557. 
13. DerSimonian R, Laird N. Meta-analysis in clinical trials. Controlled Clin Trials. 1986;7:177-188, doi: 10.1016/0197-2456(86)90046-2.

14. Begg C, Mazumdar M. Operating characteristics of a rank correlation test for publication bias. Biometrics. 1994;50:1088-1101, doi: 10.2307/ 2533446.

15. Egger M, Davey Smith G, Schneider M, Minder C. Meta-analysis: Principles and procedures. BMJ. 1997;315:1371-1374.

16. Anacker SL, Di Fabio RP. Influence of sensory inputs on standing balance in community-dwelling elders with a recent history of falling. Phys Ther. 1992;72(8):575-581.

17. Anstey KJ, von Sanden C, Luszcz MA. An 8-year prospective study of the relationship between cognitive performance and falling in very old adults. J Am Geriatr Soc. 2006;54(8):1169-1176, doi: 10.1111/j.1532-5415. 2006.00813.x.

18. Aoyagi $\mathrm{K}$, Ross PD, Davis JW, Wasnich RD. Falls among communitydwelling elderly in Japan. J Bone Miner Res. 1998;13(9):1468-1474, doi: 10.1359/jbmr.1998.13.9.1468.

19. Assantachai P, Praditsuwan R, Chatthanawaree W, Pisalsarakij D, Thamlikitkul V. Risk factors for falls in the Thai elderly in an urban community. J Med Assoc Thai. 2003;86(2):124-130.

20. Aufauvre V, Kemoun G, Carette P, Bergeal E. Home postural evaluation in the elderly: comparison between fallers and non fallers. Ann Readapt Med Phys. 2005;48(4):165-171.

21. Avdic D, Pecar D. Significance of specificity of Tinetti B-POMA test and fall risk factor in third age of life. Bosn J Basic Med Sci. 2006;6(1):50-57.

22. Avdic D, Pecar D, Mujic-Skikic E. Risk factors of fall in elderly people. Bosn J Basic Med Sci. 2004;4(4):71-78.

23. Bath PA, Morgan K. Differential risk factor profiles for indoor and outdoor falls in older people living at home in Nottingham, UK. Eur J Epidemiol. 1999;15(1):65-73, doi: 10.1023/A:1007531101765.

24. van Bemmel T, Vandenbroucke JP, Westendorp RGJ, Gussekloo J. In an observational study elderly patients had an increased risk of falling due to home hazards. Journal of Clinical Epidemiology. 2005;58(1):63-67, doi: 10.1016/j.jclinepi.2004.06.007.

25. Berg WP, Alessio HM, Mills EM, Tong C. Circumstances and consequences of falls in independent community-dwelling older adults. Age Ageing. 1997;26:261-268, doi: 10.1093/ageing/26.4.261.

26. Berger L, Chuzel M, Buisson G, Rougier P. Undisturbed upright stance control in the elderly: Part 2. Postural-control impairments of elderly fallers. J Mot Behav. 2005;37(5):359-366, doi: 10.3200/JMBR.37.5.359-366.

27. Bergland A, Pettersen AM, Laake K. Falls reported among elderly Norwegians living at home. Physiother Res Int. 1998;3(3):164-174, doi: 10.1002/pri.138.

28. Blake AJ, Morgan K, Bendall MJ, Dallosso H. Falls by elderly people at home: prevalence and associated factors. Age Ageing. 1988;17(6):365372, doi: 10.1093/ageing/17.6.365.

29. Bootsma-van der Wiel A, Gussekloo J, de Craen AJ, van Exel E, Bloem BR, Westendorp RG. Walking and talking as predictors of falls in the general population: the Leiden 85-Plus Study. J Am Geriatr Soc. 2003;51(10):1466-1471, doi: 10.1046/j.1532-5415.2003.51468.x.

30. Brassington GS, King AC, Bliwise DL. Sleep problems as a risk factor for falls in a sample of community-dwelling adults aged 64-99 years. J Am Geriatr Soc. 2000;48(10):1234-1240.

31. Brauer SG, Burns YR, Galley P. A prospective study of laboratory and clinical measures of postural stability to predict community-dwelling fallers. J Gerontol A Biol Sci Med Sci. 2000;55(8):M469-M476.

32. Buatois S, Gueguen R, Gauchard GC, Benetos A, Perrin PP. Posturography and risk of recurrent falls in healthy non-institutionalized persons aged over 65. Gerontology. 2006;52(6):345-352, doi: 10. $1159 / 000094983$

33. Campbell AJ, Borrie MJ, Spears GF. Risk factors for falls in a community-based prospective study of people 70 years and older. J Gerontol. 1989;44(4):M112-M117.

34. Cesari M, Landi F, Torre S, Onder G, Lattanzio F, Bernabei R. Prevalence and risk factors for falls in an older community-dwelling population. J Gerontol A Biol Sci Med Sci. 2002;57(11):M722-M726.

35. Chan KM, Pang WS, Ee CH, Ding YY, Choo P. Epidemiology of falls among the elderly community dwellers in Singapore. Singapore Med J. 1997;38(10):427-431.

36. Chu LW, Chi I, Chiu AY. Incidence and predictors of falls in the chinese elderly. Ann Acad Med Singapore. 2005;34(1):60-72.

37. Coll-Planas L, Kron M, Sander S, Ribmann U, Becker C, Nikolaus T. Accidental falls among community-dwelling older adults. Gerontol Geriat. 2006;39(4):277-282, doi: 10.1007/s00391-006-0396-0.

38. Covinsky KE, Kahana E, Kahana B, Kercher K. History and mobility exam index to identify community-dwelling elderly persons at risk of falling. J Gerontol A Biol Sci Med Sci. 2001;56(4):M253-M259.

39. Cwikel J. Falls among elderly people living at home: medical and social factors in a national sample. Isr J Med Sci. 1992;28(7):446-453.

40. Delbaere K, Van den Noortgate N, Bourgois J, Vanderstraeten G, Tine W, Cambier D. The Physical Performance Test as a predictor of frequent fallers: a prospective community-based cohort study. Clinical Rehabilitation. 2006 Jan;20(1):83-90, doi: 10.1191/0269215506cr885oa.
41. Dolinis J, Harrison JE, Andrews GR. Factors associated with falling in older Adelaide residents. Aust N Z J Public Health. 1997;21(5):462-468, doi: 10.1111/j.1467-842X.1997.tb01736.x.

42. Downton JH, Andrews K. Prevalence, characteristics and factors associated with falls among the elderly living at home. Aging (Milano). 1991;3(3):219-228.

43. Duncan PW, Studenski S, Chandler J, Prescott B. Functional reach: predictive validity in a sample of elderly male veterans. J Gerontol. 1992;47(3):M93-M98.

44. Dunne RG, Bergman AB, Rogers LW, Inglin B. Elderly persons' attitudes towards footwear-a factor in preventing falls. Public Health Rep. 1993;108(2):245-248.

45. Faulkner KA, Redfern MS, Cauley JA, Landsittel DP, Studenski SA, Rosano C, et al. Multitasking: Association Between Poorer Performance and a History of Recurrent Falls. Journal of the American Geriatrics Society. 2007;55(4):570-576, doi: 10.1111/j.1532-5415.2007.01147.x.

46. Fernie GR, , Gryfe PJLA C I Holliday. The relationship of postural sway in standing to the incidence of falls in geriatric subjects. Age Ageing. 1982;11:11-16, doi: 10.1093/ageing/11.1.11.

47. Frels C, Williams P, Narayanan S, Gariballa SE. Iatrogenic causes of falls in hospitalised elderly patients: a case-control study. Postgrad Med J. 2002;78(922):487-489, doi: 10.1136/pmj.78.922.487.

48. Gehlsen GM WM. Falls in the elderly: Part I, Gait. Arch Phys Med Rehabil. 1990;71:7435-7438.

49. Gerdhem P, Ringsberg KAM, Akesson K, Obrant KJ. Clinical history and biologic age predicted falls better than objective functional tests. Journal of Clinical Epidemiology. 2005;58(3):226-232, doi: 10.1016/j. jclinepi.2004.06.013.

50. Giles LC, Whitehead CH, Jeffers L, McErlean B, Thompson D, Crotty M. Falls in hospitalized patients: can nursing information systems data predict falls? Comput Inform Nurs. 2006;24(3):167-172, doi: 10.1097/ 00024665-200605000-00014.

51. Gill T, Taylor AW, Pengelly A. A population-based survey of factors relating to the prevalence of falls in older people. Gerontology. 2005;51: 340-345, doi: 10.1159/000086372.

52. Gluck T, Wientjes HJ, Rai GS. An evaluation of risk factors for in-patient falls in acute and rehabilitation elderly care wards. Gerontology. 1996;42(2):104-7, doi: 10.1159/000213779.

53. Graafmans WC, Ooms ME, Hofstee HM, Bezemer P. Falls in the elderly: a prospective study of risk factors and risk profiles. Am J Epidemiol. 1996;143(11):1129-1136.

54. Hale WA, Delaney MJ, McGaghie WC. Characteristics and predictors of falls in elderly patients. J Fam Pract. 1992;34(5):577-81.

55. Herndon JG, Helmick CG, Sattin RW, Stevens J. Chronic medical conditions and risk of fall injury events at home in older adults. J Am Geriatr Soc. 1997;45(6):739-743.

56. Huang HC, Gau ML, Lin WC, George K. Assessing Risk of Falling in Older Adults. Public Health Nursing. 2003;20(5):399-411, doi: 10.1046/j. 1525-1446.2003.20508.x.

57. Huang HC. A checklist for assessing the risk of falls among the elderly. J Nurs Res. 2004;12(2):131-142.

58. Ishizuka MA, Mutarelli EG, Yamaguchi AM, Jacob Filho W. Falls by elders with moderate levels of movement functionality. Clinics. 2005;60(1):41-46, doi: 10.1590/S1807-59322005000100009.

59. Janssen HC, Samson MM, Meeuwsen IB, Duursma SA, Verhaar HJ. Strength, mobility and falling in women referred to a geriatric outpatient clinic. Aging Clin Exp Res. 2004;16(2):122-125.

60. Jantti PO, Pyykko VI, Hervonen AL. Falls among elderly nursing home residents. Public Health. 1993;107(2):89-96, doi: 10.1016/S00333506(05)80404-4.

61. Johnson CS. The association between nutritional risk and falls among frail elderly. J Nutr Health Aging. 2003;7(4):247-250.

62. Jonsson PV, Lipsitz LA, Kelley M, Koestner J. Hypotensive responses to common daily activities in institutionalized elderly. A potential risk for recurrent falls. Arch Intern Med. 1990;150(7):1518-1524, doi: 10.1001/ archinte.150.7.1518

63. Kallin K, Jensen J, Olsson LL, Nyberg L, Gustafson Y. Why the elderly fall in residential care facilities, and suggested remedies. J Fam Pract. 2004;53(1):41-52

64. Kallin K, Gustafson Y, Sandman PO, Karlsson S. Drugs and falls in older people in geriatric care settings. Aging Clin Exp Res. 2004;16(4):270-276.

65. Kelly KD, Pickett W, Yiannakoulias N, Rowe BH, Schopflocher DP, Svenson L, et al. Medication use and falls in community-dwelling older persons. Age Ageing. 2003 Sep;32(5):503-509, doi: 10.1093/ageing/ afg081.

66. Kerman M, Mulvihill M. The role of medication in falls among the elderly in a long-term care facility. Mt Sinai J Med. 1990;57:343-347.

67. Koepsell TD, Wolf ME, Buchner DM, Kukull WA, LaCroix AZ, Tencer $\mathrm{AF}$, et al. Footwear Style and Risk of Falls in Older Adults. Journal of the American Geriatrics Society. 2004;52(9):1495-1501, doi: 10.1111/j. 1532-5415.2004.52412.x. 
68. Kron M, Loy S, Sturm E, Nikolaus T, Becker C. Risk Indicators for Falls in Institutionalized Frail Elderly. Am J Epidemiol. 2003;158(7):645-653, doi: $10.1093 /$ aje/kwg203.

69. Lach HW, Reed AT, Arfken CL, Miller JP. Falls in the elderly: reliability of a classification system. J Am Geriatr Soc. 1991;39(2):197-202.

70. Laessoe U, Hoeck HC, Simonsen O, Sinkjaer T, Voigt M. Fall risk in an active elderly population-can it be assessed? J Negat Results Biomed. 2007;6:2, doi: 10.1186/1477-5751-6-2.

71. Lajoie Y, Gallagher SP. Predicting falls within the elderly community: comparison of postural sway, reaction time, the Berg balance scale and the Activities-specific Balance Confidence (ABC) scale for comparing fallers and non-fallers. Archives of Gerontology and Geriatrics. 2004;38(1):11-26, doi: 10.1016/S0167-4943(03)00082-7.

72. Landi F, Onder G, Cesari M, Barillaro C, Russo A, Bernabei R, et al. Psychotropic Medications and Risk for Falls Among CommunityDwelling Frail Older People: An Observational Study. J Gerontol A Biol Sci Med Sci. 2005;60(5):622-626.

73. Langlois JA, Smith GS, Nelson DE, Sattin R. Dependence in activities of daily living as a risk factor for fall injury events among older people living in the community. J Am Geriatr Soc. 1995;43(3):275-278.

74. Latimer Hill ERG, Lewis R, Carrington S, Le Couteur DG. Sleep Disturbances and Falls in Older People. J Gerontol A Biol Sci Med Sci. 2007 Jan;62(1):62-66.

75. Lau EM, Woo J, Lam D. Neuromuscular impairment: a major cause of non-syncopal falls in elderly Chinese. Public Health. 1991;105(5):369372, doi: 10.1016/S0033-3506(05)80596-7.

76. Lawlor DA, Patel R, Ebrahim S. Association between falls in elderly women and chronic diseases and drug use: cross sectional study. BMJ. 2003;327(7417):712-717, doi: 10.1136/bmj.327.7417.712

77. Lipsitz LA, Jonsson PV, Kelley MM, Koestner JS. Causes and correlates of recurrent falls in ambulatory frail elderly. J Gerontol. 1991; 46(4):M114-M122.

78. Lipsitz LA, Nakajima I, Gagnon M, Hirayama T. Muscle strength and fall rates among residents of Japanese and American nursing homes: an International Cross-Cultural Study. J Am Geriatr Soc. 1994;42(9): 953-959.

79. Liu BA, Topper AK, Reeves RA, Gryfe C, Maki BE. Falls among older people: relationship to medication use and orthostatic hypotension. J Am Geriatr Soc. 1995;43(10):1141-1145.

80. Lord SR, Ward JA, Williams P, Anstey KJ. An epidemiological study of falls in older community-dwelling women: the Randwick falls and fractures study. Aust J Public Health. 1993;17(3):240-245, doi: 10.1111/j. 1753-6405.1993.tb00143.x.

81. Lord SR, March LM, Cameron ID, Cumming RG, Schwarz J, Zochling J, et al. Differing Risk Factors for Falls in Nursing Home and Intermediate-Care Residents Who Can and Cannot Stand Unaided. Journal of the American Geriatrics Society. 2003;51(11):1645-1650, doi: 10.1046/j.1532-5415.2003.51518.x

82. Lundin-Olsson L, Jensen J, Nyberg L, Gustafson Y. Predicting falls in residential care by a risk assessment tool, staff judgement, and history of falls. Aging Clin Exp Res. 2003;15(1):51-59.

83. Luukinen H, Koski K, Laippala P, Kivela SL. Predictors for recurrent falls among the home-dwelling elderly. Scand J Prim Health Care. 1995;13(4):294-299, doi: 10.3109/02813439508996778.

84. Luukinen H, Koski K, Kivela SL, Laippala P. Social status, life changes, housing conditions, health, functional abilities and life-style as risk factors for recurrent falls among the home-dwelling elderly. Public Health. 1996;110(2):115-118, doi: 10.1016/S0033-3506(96)80057-6.

85. Mahoney J, Sager M, Dunham NC, Johnson J. Risk of falls after hospital discharge. J Am Geriatr Soc. 1994;42(3):269-274

86. Maki BE, Holliday PJ, Topper AK. A prospective study of postural balance and risk of falling in an ambulatory and independent elderly population. J Gerontol. 1994, 49, M72-M84.

87. Maki BE. Gait changes in older adults: predictors of falls or indicators of fear. J Am Geriatr Soc. 1997;45(3):313-320.

88. Means KM, Rodell DE, O'Sullivan PS. Obstacle course performance and risk of falling in community-dwelling elderly persons. Arch Phys Med Rehabil. 1998;79(12):1570-1576, doi: 10.1016/S0003-9993(98)90423-3.

89. Melzer I, Benjuya N, Kaplanski J. Postural stability in the elderly: a comparison between fallers and non-fallers. Age Ageing. 2004; 33(6):602-607, doi: 10.1093/ageing/afh218.

90. Menz HB, Morris ME, Lord SR. Footwear characteristics and risk of indoor and outdoor falls in older people. Gerontology. 2006;52(3):174180, doi: 10.1159/000091827.

91. Menz HB, Morris ME, Lord SR. Foot and ankle risk factors for falls in older people: a prospective study. J Gerontol A Biol Sci Med Sci. 2006;61(8):866-870.

92. Moreira MD, Costa AR, L RF, Caldas CP. The association between nursing diagnoses and the occurrence of falls observed among elderly individuals assisted in an outpatient facility. Rev Lat Am Enfermagem. 2007;15(2):311-317

93. Morita M, Takamura N, Kusano Y, Abe Y, Moji K, Takemoto T, et al. Relationship between falls and physical performance measures among community-dwelling elderly women in Japan. Aging Clin Exp Res. 2005;17(3):211-216.

94. Morris M, Osborne D, Hill K, Kendig H, Lundgren-Lindquist B Browning $\mathrm{C}$, et al. Predisposing factors for occasional and multiple falls in older Australians who live at home. Aust J Physiother. 2004;50(3): 153-159.

95. Murphy MA, Olson SL, Protas EJ, Overby AR. Screening for Falls in Community-Dwelling Elderly. Journal of Aging and Physical Activity. 2003:11:64-78.

96. Murray KJ, Hill K, Phillips B, Waterston J. A pilot study of falls risk and vestibular dysfunction in older fallers presenting to hospital emergency departments. Disabil Rehabil. 2005;27(9):499-506, doi: 10.1080/ 09638280400018486

97. Nelson DE, Sattin RW, Langlois JA, DeVito C. Alcohol as a risk factor for fall injury events among elderly persons living in the community. J Am Geriatr Soc. 1992;40(7):658-661.

98. Northridge ME, Nevitt MC, Kelsey JL, Link B. Home hazards and falls in the elderly: the role of health and functional status. Am J Public Health. 1995;85(4):509-515, doi: 10.2105/AJPH.85.4.509.

99. Nowalk MP, Prendergast JM, Bayles CM, D'Amico FJ, Colvin JC. A randomized trial of exercise programs among older individuals living in two long-term care facilities: the FallsFREE program. J Am Geriatr Soc. 2001:49(7):859-865, doi: 10.1046/j.1532-5415.2001.49174.x.

100. O'Loughlin JL, Robitaille Y, Boivin JF, Suissa S. Incidence of and risk factors for falls and injurious falls among the community-dwelling elderly. Am J Epidemiol. 1993;137(3):342-354.

101. Ooi WL, Hossain M, Lipsitz LA. The association between orthostatic hypotension and recurrent falls in nursing home residents. Am J Med. 2000;108(2):106-111, doi: 10.1016/S0002-9343(99)00425-8.

102. Pajala S, Era P, Koskenvuo M, Kaprio J, Viljanen A, Rantanen T. Genetic Factors and Susceptibility to Falls in Older Women. Journal of the American Geriatrics Society. 2006;54(4):613-618, doi: 10.1111/j.15325415.2006.00678.x

103. Passaro A, Volpato S, Romagnoni F, Manzoli N. Benzodiazepines with different half-life and falling in a hospitalized population: The GIFA study. Gruppo Italiano di Farmacovigilanza nell'Anziano. J Clin Epidemiol. 2000;53(12):1222-1229, doi: 10.1016/S0895-4356(00)00254-7.

104. Peel NM, McClure RJ, Hendrikz JK. Health-protective behaviours and risk of fall-related hip fractures: a population-based case-control study. Age Ageing. 2006;35(5):491-497, doi: 10.1093/ageing/afl056.

105. Peel NM, McClure RJ, Hendrikz JK. Psychosocial factors associated with fall-related hip fractures. Age Ageing. 2007;36(2):145-151, doi: 10 1093/ageing/afl167.

106. Quandt SA, Stafford JM, Bell RA, Smith SL, Snively BM, Arcury TA Predictors of Falls in a Multiethnic Population of Older Rural Adults With Diabetes. J Gerontol A Biol Sci Med Sci. 2006;61(4):394-398.

107. de Rekeneire N, Visser M, Peila R, Nevitt MC, Cauley JA, Tylavsky FA, et al. Is a Fall Just a Fall: Correlates of Falling in Healthy Older Persons. The Health, Aging and Body Composition Study. Journal of the American Geriatrics Society. 2003;51(6):841-846, doi: 10.1046/j.13652389.2003.51267.x

108. Reyes-Ortiz CA, Al Snih S, Loera J, Ray LA, Markides K. Risk factors for falling in older Mexican Americans. Ethn Dis. 2004;14(3):417-422.

109. Reyes-Ortiz CA, Al Snih S, Markides KS. Falls among elderly persons in Latin America and the Caribbean and among elderly MexicanAmericans. Rev Panam Salud Publica. 2005;17(5-6):362-369.

110. Robbins AS, Rubenstein LZ, Josephson KR, Schulman BL, Osterweil D, Fine G. Predictors of falls among elderly people. Results of two population-based studies. Arch Intern Med. 1989;149(7):1628-1633, doi: 10.1001/archinte.149.7.1628.

111. Rosendahl E, Lundin-Olsson L, Kallin K, Jensen J, Gustafson Y, Nyberg L. Prediction of falls among older people in residential care facilities by the Downton index. Aging Clin Exp Res. 2003;15(2):142-147.

112. Ruthazer R, Lipsitz LA. Antidepressants and falls among elderly people in long-term care. Am J Public Health. 1993;83(5):746-749, doi: 10.2105/ AJPH.83.5.746.

113. Saari P, Heikkinen E, Sakari-Rantala R, Rantanen T. Fall-related injuries among initially 75- and 80-year old people during a 10-year follow-up. Arch Gerontol Geriatr. 2007;45(2):207-215, doi: 10.1016/j.archger.2006 10.012.

114. Salvà A, Bolibar I, Pera G, Arias C. Incidence and consequences of falls among elderly people living in the community. Med Clin. 2004;122(5):172-176, doi: 10.1157/13057813

115. Sambrook PN, Chen JS, March LM, Cameron ID, Cumming RG, Lord SR, et al. Serum Parathyroid Hormone Predicts Time to Fall Independent of Vitamin D Status in a Frail Elderly Population. J Clin Endocrinol Metab. 2004;89(4):1572-1576, doi: 10.1210/jc.2003-031782.

116. Sattin RW, Rodriguez JG, DeVito CA, Wingo P. Home environmental hazards and the risk of fall injury events among community-dwelling older persons. Study to Assess Falls Among the Elderly (SAFE) Group. J Am Geriatr Soc. 1998;46(6):669-676.

117. Shumway-Cook A, Gruber W, Baldwin M, Liao S. The effect of multidimensional exercises on balance, mobility, and fall risk in community-dwelling older adults. Phys Ther. 1997;77(1):46-57. 
118. Sieri T, Beretta G. Fall risk assessment in very old males and females living in nursing homes. Disability and Rehabilitation. 2004;26(12): 718-723, doi: 10.1080/09638280410001704304.

119. Sobel KG, McCart GM. Drug use and accidental falls in an intermediate care facility. Drug Intell Clin Pharm. 1983;17:539-542.

120. Sorock GS, Labiner DM. Peripheral neuromuscular dysfunction and falls in an elderly cohort. Am J Epidemiol. 1992;136(5):584-591.

121. Stalenhoef PA, Diederiks JP, Knottnerus JA. The construction of a patient record-based risk model for recurrent falls among elderly people living in the community. Fam Pract. 2000;17(6):490-496, doi: 10. 1093/fampra/17.6.490.

122. Stel VS, Smit JH, Pluijm SMF, Lips P. Balance and mobility performance as treatable risk factors for recurrent falling in older persons. Journal of Clinical Epidemiology. 2003 Jul;56(7):659-668, doi: 10.1016/S08954356(03)00082-9.

123. Stel VS, Pluijm SMF, Deeg DJH, Smit JH, Bouter LM, Lips P. A Classification Tree for Predicting Recurrent Falling in CommunityDwelling Older Persons. Journal of the American Geriatrics Society. 2003;51(10):1356-1364. Available from: http://www.blackwell-synergy. com/doi/abs/10.1046/j.1532-5415.2003.51452.x, doi: 10.1046/j.15325415.2003.51452.x.

124. Stewart RB, Moore MT, May FE, Marks RG. Nocturia: a risk factor for falls in the elderly. J Am Geriatr Soc. 1992;40(12):1217-1220.

125. Suzuki M, Shimamoto Y, Kawamura I, Takahasi H. Does gender make a difference in the risk of falls? A Japanese study. J Gerontol Nurs. 1997;23(1):41-48.

126. Svensson ML, Rundgren A, Landahl S. Falls in 84- to 85-year-old people living at home. Accid Anal Prev. 1992;24:527-537, doi: 10.1016/00014575(92)90061-M.

127. Takazawa K, Arisawa K. Relationship between the type of urinary incontinence and falls among frail elderly women in Japan. J Med Invest. 2005;52(3-4):165-171, doi: 10.2152/jmi.52.165.

128. Teno J, Kiel DP, Mor V. Multiple stumbles: a risk factor for falls in community-dwelling elderly. A prospective study. J Am Geriatr Soc. 1990;38(12):1321-1325.

129. Teo JS, Briffa NK, Devine A, Dhaliwal SS, Prince RL. Do sleep problems or urinary incontinence predict falls in elderly women? Aust J Physiother. 2006;52(1):19-24.

130. Thapa PB, Gideon P, Fought RL, Ray WA. Psychotropic drugs and risk of recurrent falls in ambulatory nursing home residents. Am J Epidemiol. 1995;142(2):202-211.

131. Thomas JI, Lane JV. A pilot study to explore the predictive validity of 4 measures of falls risk in frail elderly patients. Arch Phys Med Rehabil. 2005;86(8):1636-1640, doi: 10.1016/j.apmr.2005.03.004.

132. Thrane G, Joakimsen RM, Thornquist E. The association between timed up and go test and history of falls: the Tromso study. BMC Geriatr. 2007;7:1, doi: 10.1186/1471-2318-7-1.

133. Tinetti ME, Speechley M, Ginter SF. Risk factors for falls among elderly persons living in the community. N Engl J Med. 1988;319(26):1701-1707, doi: 10.1056/NEJM198812293192604.

134. Tinetti ME, Williams TF, Mayewski R. Fall risk index for elderly patients based on number of chronic disabilities. Am J Med. 1986;80:429-434, doi: 10.1016/0002-9343(86)90717-5.

135. Toulotte C, Thevenon A, Watelain E, Fabre C. Identification of healthy elderly fallers and non-fallers by gait analysis under dual-task conditions. Clin Rehabil. 2006;20(3):269-276, doi: 10.1191/ 0269215506cr929oa.
136. Trewin VF, Lawrence CJ, Veitch GB. An investigation of the association of benzodiazepines and other hypnotics with the incidence of falls in the elderly. J Clin Pharm Ther. 1992;17(2):129-133.

137. Vassallo M, Sharma JC, Allen SC. Characteristics of single fallers and recurrent fallers among hospital in-patients. Gerontology. 2002;48(3): 147-150, doi: 10.1159/000052833.

138. Verghese J, Buschke H, Viola L, Katz M, Hall C, Kuslansky G, et al. Validity of divided attention tasks in predicting falls in older individuals: a preliminary study. J Am Geriatr Soc. 2002;50(9):15721576, doi: 10.1046/j.1532-5415.2002.50415.x.

139. Wickham C, Cooper C, Margetts BM, Barker DJ. Muscle strength, activity, housing and the risk of falls in elderly people. Age Ageing. 1989;18:47-51, doi: 10.1093/ageing/18.1.47.

140. Wild D, Nayak US, Isaacs B. How dangerous are falls in old people at home? Br Med J. 1981;6260:266-268, doi: 10.1136/bmj.282.6260.266.

141. Yip YB, Cumming RG. The association between medications and falls in Australian nursing-home residents. Med J Aust. 1994;160(1):14-18.

142. Yokoya T, Demura S, Sato S. Relationships between physical activity, ADL capability and fall risk in community-dwelling Japanese elderly population. Environ Health Prev Med. 2007;12:25-32, doi: 10.1007/ BF02898189.

143. Oka H, Yoshimura N, Kinoshita H, Saiga A, Kawaguchi H, Nakamura K. Decreased activities of daily living and associations with bone loss among aged residents in a rural Japanese community : the Miyama Study. Journal of bone and mineral metabolism. 2006;24:307-313, doi: 10.1007/s00774-006-0688-x.

144. Tinetti ME, Richman D, Powell L. Falls efficacy as a measure of fear of falling. J Gerontol. 1990;45:P239-P243.

145. Cumming RG, Salkeld G, Thomas M, Szonyi G. Prospective Study of the Impact of Fear of Falling on Activities of Daily Living, SF-36 Scores, and Nursing Home Admission. J Gerontol A Biol Sci Med Sci. 2000;55:M299-M305.

146. Stevens JA, Dellinger AM. Motor vehicle and fall related deaths among older Americans 1990 -98: sex, race, and ethnic. Disparities Inj Prev. 2002;8:272-275, doi: 10.1136/ip.8.4.272.

147. House JS, Landis KR, Umberson D. Social relationships and health. Science. 1988;241:540-545, doi: 10.1126/science.3399889.

148. Christakis NA, Allison PD. Mortality after the hospitalization of a spouse. N Engl J Med. 2006;354:719-31, doi: 10.1056/NEJMsa050196.

149. Manzoli L, Villari PM, Pirone G, Boccia A. Marital status and mortality in the elderly: a systematic review and meta-analysis. Soc Sci Med. 2007;64:77-94, doi: 10.1016/j.socscimed.2006.08.031.

150. Thoits PA. Stress, coping, and social support processes: where are we? What next?J Health Social Behav. 1995;Special N:53-79, doi: 10.2307/ 2626957.

151. Kemoun G, Thibaud M, Roumagne N, Carette P, Albinet C, Toussaint L, Paccalin M, Dugué B. Effects of a physical training programme on cognitive function and walking efficiency in elderly persons with dementia. Dement Geriatr Cogn Disord. 2010;29(2):109-114, doi: 10. $1159 / 000272435$.

152. Gillespie L. Preventing falls in elderly people. BMJ. 2004;328:653-654, doi: $10.1136 /$ bmj.328.7441.653.

153. American Geriatrics Society BGS, of Orthopaedic Surgeons Panel on Falls Prevention AA. Guideline for the prevention of falls in older persons. J Am Geriatr Soc. 2001;49:664-672, doi: 10.1046/j.1532-5415. 2001.49115.x. 